\title{
The Effect of Growth Regulators and a Biostimulator on the Health Status, Yield and Yield Components of Potatoes (Solanum tuberosum L.)
}

\author{
Małgorzata Głosek-Sobieraj ${ }^{1}$ Bożena Cwalina-Ambroziak ${ }^{1} \cdot$ Karel Hamouz $^{2}$
}

Received: 19 October 2017 / Accepted: 1 November 2017 / Published online: 6 December 2017

(c) The Author(s) 2017. This article is an open access publication.

\begin{abstract}
In this study, the influence of potato cultivars Irga, Satina, Valfi, Blaue St. Galler and Highland Burgundy Red (HB Red), growth regulators: Bio-Algeen S-90, Kelpak SL and Trifender WP, and the biostimulator Asahi SL on the health status of potato plants and tuber yield was investigated. The severity of late blight and early blight was estimated during the growing season. After harvest, potato tuber yield was determined according to size fractions. The applied treatments significantly reduced the severity of late blight in cv. Irga (Kelpak SL), Valfi (Bio-Algeen S-90, Kelpak SL, Trifender WP) and Blaue St. Galler (Trifender WP) in 2013. In 2015, the symptoms of early blight were significantly reduced in cv. Irga after the application of all tested bioregulators. HB Red was characterized by the best health status among the evaluated cultivars. Kelpak SL and BioAlgeen S-90 increased the tuber yield of cvs. Irga and HB Red, respectively, in 2013, and Trifender WP increased the tuber yield of cv. Satina in 2014. In the first year of the study, the applied growth regulators and biostimulator significantly increased the percentage of medium-sized tubers of cv. Blaue St. Galler, and Bio-Algeen S-90 increased the percentage of medium-sized tubers of $\mathrm{cv}$. HB Red.
\end{abstract}

Keywords Solanum tuberosum L · Late blight · Early blight · Yield · Growth regulators

Małgorzata Głosek-Sobieraj

malgorzata.glosek@uwm.edu.pl

1 Department of Entomology, Phytopathology and Molecular Diagnostics, University of Warmia and Mazury, Olsztyn, Poland

2 Department of Plant Production, Czech University of Life Sciences in Prague, Prague, Czech Republic
Einfluss der Wachstumsregulatoren und des Biostimulators auf die Gesundheit, den Ertrag und Komponenten der Kartoffel (Solanum tuberosum L.)

Zusammenfassung In den Untersuchungen wurde die Wirkung der Kartoffelsorten: Irga, Satina, Valfi, Blaue St. Galler, Highland Burgundy Red (HB-Red) und der Anwendung von Wachstumsregulatoren: Bio-Algeen S-90, Kelpak SL, Trifender WP und des Biostimulators Asahi SL auf die Gesundheit der Pflanzen und den Ertrag der Kartoffelknollen untersucht. Während der Vegetation wurde der Intensitätsgrad der Kartoffelfäule und der Dürrfleckenkrankheit eingeschätzt und nach der Ernte wurde der Knollenertrag mit Berücksichtigung der Unterteilung in Fraktionen berechnet. Angewandte Wachstumsregulatoren haben im Jahr 2013 die Intensität der Kartoffelfäule an der Kartoffelsorte Irga (Kelpak SL), Valfi (Bio-Algeen S-90, Kelpak SL, Trifender WP) und Blaue St. Galler (Trifender WP) deutlich reduziert. Im Jahre 2015 waren die Anzeichen von Dürffleckenkrankheit an der Kartoffelsorte Irga nach Anwendung aller angewandten Wachstumsregulatoren deutlich eingeschränkt. Die Kartoffelsorte HB Red erwies sich als die gesündeste der getesteten Sorten. Kelpak SL und Bio-Algeen S-90 führten im Jahr 2013 zu einer Erhöhung des Knollenertrags entsprechend der Sorte Irga und HB Red, und Trifender WP verursachte im Jahr 2014 das Wachstum des Knollenertrags der Sorte Satina. Im ersten Untersuchungsjahr haben angewandte Wachstumsregulatoren und der Biostimulator den prozentuellen Anteil an mittelgroßen Knollen der Sorte Blaue St. Galler wesentlich gesteigert, und Bio-Algeen S90 verursachte eine Erhöhung des prozentuellen Anteils der mittelgroßen Knollen der Sorte HB Red. 
Schlüsselwörter Solanum tuberosum L · Kartoffelfäule . Dürrfleckenkrankheit · Ertrag · Wachstumsregulator

\section{Introduction}

Late blight (Phytophthora infestans) is the most devastating disease in potato farms during the growing season (Fry 2008; Bradeen et al. 2009; Chmielarz et al. 2014; Mosquera et al. 2016). Under favorable conditions, the pathogen can significantly lower yields, and late blight epidemics can result in the destruction of entire harvests. The annual losses sustained due to $P$. infestans around the world are estimated at USD 5 billion, and the pathogen poses a significant threat to global food safety (Latijnhouwers et al. 2004). In Poland, the losses in unprotected potato farms are much higher than in other countries and are estimated at $21-57 \%$. The above can be attributed to the fact that potatoes are a major crop in Poland and that the Polish climate creates favorable conditions for the development of P. infestans (Kapsa 2005). Tubers are directly infected by the pathogen, which lowers the quality of the stored potatoes and increases their susceptibility to secondary fungal and bacterial infections (Smart and Fry 2001). The incidence of early blight caused by Alternaria alternata and A. solani is also on the rise, and A. alternata is the prevalent species in the temperate climate (Gudmestad and Pasche 2007; Kapsa 2007). In many regions of the world, the increase in the incidence of early blight can be attributed to climate change and global warming (Hausladen and Leiminger 2007). Yield losses caused by early blight are generally estimated at $20 \%$, but they can reach $70-80 \%$ in unprotected potato farms (Soleimani and Kirk 2012). According to integrated pest management strategies (Directive 2009/128/EC of the European Parliament and of the Council of 21 October 2009, Regulation (EC) No 1107/2009 of the European Parliament and of the Council of 21 October 2009), pathogen populations should be regularly monitored and invasive genotypes should be identified (Kapsa and Hansen 2004). Crop losses can also be minimized by cultivating potato cultivars that are more resistant to pathogens (Cooke et al. 2011). Potato cultivars with colored flesh contain 2 to 10 times more phenolic acids than traditional cultivars with yellow flesh (Brown 2005; Hamouz et al. 2010; Ezekiel et al. 2013; Bellumori et al. 2017), and they are more resistant to stressors, including pathogens (Tierno and Ruiz de Galarreta 2016). Dixon (2001), Mandal et al. (2010) and Terry et al. (2014) demonstrated that phenolic compounds participate in defense responses in plants exposed to pathogens.

Growth promoters and regulators are increasingly used in agricultural practice to stimulate the development of plants and increase their resistance to abiotic and biotic stresses (Ziosi et al. 2013; Sharma et al. 2014; Bulgari et al. 2015).
According to Sawicka and Skiba (2009), Kowalska and Remlein-Starosta (2012) and Uromova et al. (2016), growth regulators compromise the health of potato plants during the growing season. The number of chemical treatments that protect potatoes against late blight and early blight can be reduced through the cultivation of cultivars with increased concentrations of phenolic compounds, and the use of products that stimulate the growth and development of potato plants.

The aim of this study was to determine the effect of a biostimulator (Asahi SL) and growth regulators (Bio-Algeen S-90, Kelpak SL, Trifender WP) on the severity of late blight and early blight in potato cultivars with differently colored flesh, tuber yield and yield components.

\section{Materials and Methods}

\section{Field Experiment}

A micro-plot experiment with a randomized sub-block design and three replications was conducted in Tomaszkowo near Olsztyn $\left(53^{\circ} 41^{\prime} \mathrm{N}, 20^{\circ} 24^{\prime} \mathrm{E}\right)$ in $2013-2015$. Five cultivars of edible potatoes were cultivated, including two cultivars with cream- and yellow-colored flesh-Irga (Poland) and Satina (Germany), two cultivars with purple-colored flesh-Valfi (Czech Republic) and Blaue St. Galler (Switzerland), and one cultivar with red-colored flesh-Highland Burgundy Red (France and Great Britain). Potato cultivars with cream- and yellow-colored flesh (Irga and Satina) are listed in the National Register of Plant Varieties, and they are characterized by high susceptibility to Phytophthora infestans (severity score of 2 to 3 points). The experiment was carried out on podzolic soil with the granulometric composition of light loam, characterized by high suitability for the cultivation of rye (suitability complex 4) and quality class IIIb (WRB 2014). Potatoes were grown in soil with the following parameters: $\mathrm{pH}$ in $\mathrm{KCl}$ 4.04-4.54 (PN ISO 10390:1997); levels of available minerals: $P-85.6-111.8 \mathrm{mg} \mathrm{kg}^{-1}$ soil (PN-R-04023:1996), K-104.2-204.2 $\mathrm{mg} \mathrm{kg}^{-1}$ soil (PNR-04022:1996 + Az1:2002), Mg-38.0-42.0 mg kg-1 soil (PN-R-04020:1994 + Az1:2004); organic carbon content-10.4-10.8 $\mathrm{g} \mathrm{kg}^{-1}$ and nitrogen total-0.71-0.76 g $\mathrm{kg}^{-1}$ (PB 29 ed. 4 27.11.2014). The content of exchangeable bases in $\mathrm{mg} \mathrm{kg}^{-1}$ soil was determined by flame photometry at: $\mathrm{K}-130.0-244.0 ; \mathrm{Ca}-350.0-517.0 ; \mathrm{Na}-120.0-140.0$ and $\mathrm{Mg}-50.0-55.0$ (Chemical and Agricultural Station in Olsztyn). Cereals were the preceding crops: winter rye in 2013, winter triticale in 2014 and oats in 2015. Farmyard manure (FYM) was applied in autumn at $25 \mathrm{t} \mathrm{ha}^{-1}$, and mineral fertilizers were applied in spring at $40 \mathrm{~kg} \mathrm{~N}^{-1}$ (46\% urea), $60 \mathrm{~kg} \mathrm{P} \mathrm{ha}^{-1}$ (17.45\% P, superphosphate) and 
Table 1 Weather conditions - data provided by the Meteorological Station in Tomaszkowo (2013-2015)

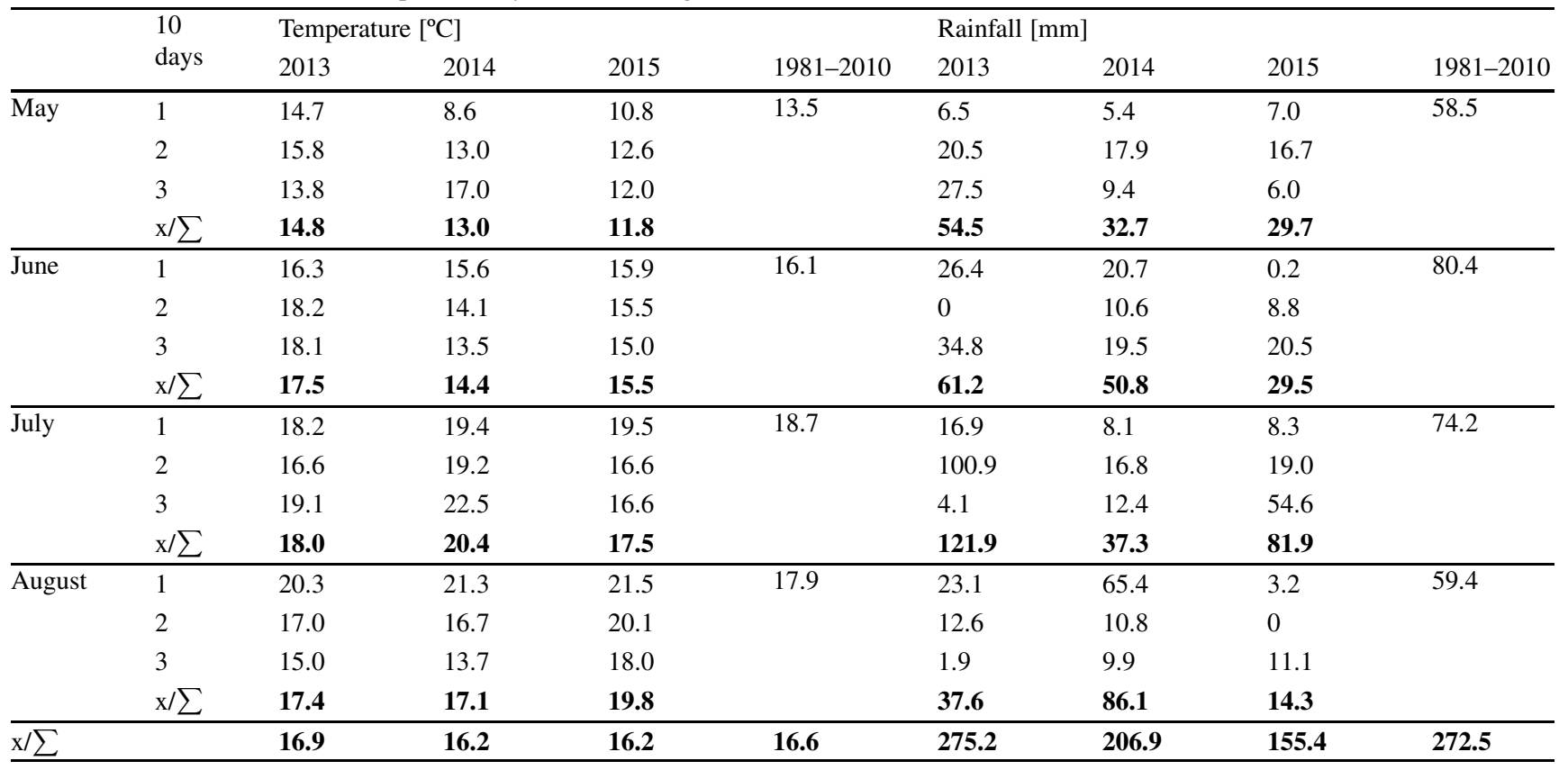

Table 2 Infection of potato plants by Phytophthora infestans (Ii \%)

\begin{tabular}{|c|c|c|c|c|c|c|c|c|c|c|c|c|c|c|c|}
\hline \multirow[t]{2}{*}{ Treatment } & \multicolumn{5}{|l|}{2013} & \multicolumn{5}{|l|}{2014} & \multicolumn{5}{|l|}{2015} \\
\hline & Irga & Satina & Valfi & Blaue & $\begin{array}{l}\text { HB } \\
\text { Red }\end{array}$ & Irga & Satina & Valfi & Blaue & $\begin{array}{l}\text { HB } \\
\text { Red }\end{array}$ & Irga & Satina & Valfi & Blaue & $\begin{array}{l}\text { HB } \\
\text { Red }\end{array}$ \\
\hline$\overline{\text { Control }}$ & $34.2^{\mathrm{ef}}$ & $30.3^{\text {fgh }}$ & $44.1^{\mathrm{ab}}$ & $42.2^{\mathrm{abc}}$ & $23.2^{\mathrm{j}}$ & $42.4^{\mathrm{a}-\mathrm{d}}$ & $45.6^{\mathrm{a}-\mathrm{d}}$ & $40.1^{\mathrm{a}-\mathrm{d}}$ & $41.2^{\mathrm{a}-\mathrm{d}}$ & $40.2^{\mathrm{a}-\mathrm{d}}$ & $33.7^{\mathrm{a}-\mathrm{d}}$ & $29.6^{\mathrm{a}-\mathrm{e}}$ & $36.0^{\mathrm{a}}$ & $32.0^{\mathrm{a}-\mathrm{e}}$ & $18.7^{\mathrm{g}}$ \\
\hline Asahi & $30.3^{\text {fgh }}$ & $30.0^{\mathrm{fgh}}$ & $39.6^{\mathrm{bcd}}$ & $45.5^{\mathrm{a}}$ & $23.8^{\mathrm{ij}}$ & $39.3^{\mathrm{bcd}}$ & $42.7^{\mathrm{a}-\mathrm{d}}$ & $36.9^{\mathrm{cd}}$ & $41.9^{\mathrm{a}-\mathrm{d}}$ & $44.4^{\mathrm{a}-\mathrm{d}}$ & $29.2^{\mathrm{b}-\mathrm{e}}$ & $26.5^{\mathrm{ef}}$ & $32.9^{\mathrm{a}-\mathrm{e}}$ & $30.8^{\mathrm{a}-\mathrm{e}}$ & $19.1^{\mathrm{g}}$ \\
\hline Bio-Al. & $31.3^{\mathrm{fg}}$ & $25.4^{\mathrm{hij}}$ & $38.3^{\text {cde }}$ & $42.2^{\mathrm{abc}}$ & $23.2^{\mathrm{j}}$ & $41.6^{\mathrm{a}-\mathrm{d}}$ & $41.3^{\mathrm{a}-\mathrm{d}}$ & $50.1^{\mathrm{abc}}$ & $49.4^{\mathrm{abc}}$ & $46.2^{\mathrm{a}-\mathrm{d}}$ & $29.7^{\mathrm{a}-\mathrm{e}}$ & $28.5^{\mathrm{c}-\mathrm{f}}$ & $35.3^{\mathrm{ab}}$ & $32.5^{\mathrm{a}-\mathrm{e}}$ & $18.4^{\mathrm{g}}$ \\
\hline Kelp. & $28.1^{\text {ghi }}$ & $29.3^{\text {fgh }}$ & $36.9^{\mathrm{de}}$ & $41.5^{\mathrm{a}-\mathrm{d}}$ & $21.6^{\mathrm{j}}$ & $37.8^{\mathrm{cd}}$ & $38.2^{\mathrm{cd}}$ & $49.9^{\mathrm{abc}}$ & $54.8^{\mathrm{ab}}$ & $44.8^{\mathrm{a}-\mathrm{d}}$ & $31.8^{\mathrm{a}-\mathrm{e}}$ & $27.8^{\text {def }}$ & $34.7^{\mathrm{abc}}$ & $32.3^{\mathrm{a}-\mathrm{e}}$ & $19.4^{\mathrm{g}}$ \\
\hline Trif. & $29.7^{\text {fgh }}$ & $28.4^{\mathrm{ghi}}$ & $39.2^{\mathrm{cd}}$ & $36.8^{\mathrm{de}}$ & $26.2^{\text {hij }}$ & $35.6^{\mathrm{cd}}$ & $37.9^{\mathrm{cd}}$ & $31.2^{\mathrm{d}}$ & $39.0^{\mathrm{bcd}}$ & $56.1^{\mathrm{a}}$ & $30.1^{\mathrm{a}-\mathrm{e}}$ & $28.2^{\mathrm{c}-\mathrm{f}}$ & $32.8^{\mathrm{a}-\mathrm{e}}$ & $30.0^{\mathrm{a}-\mathrm{e}}$ & $22.5^{\mathrm{fg}}$ \\
\hline
\end{tabular}

Statistical data within years; values followed by the same letters do not differ significantly at $P \leq 0.05$

Asahi Asahi SL, Bio-Al. Bio-Algeen S-90, Kelp. Kelak SL, Trif. Trifender WP

$100 \mathrm{~kg} \mathrm{~K} \mathrm{ha}^{-1}$ (50\% $\mathrm{K}$, potash salt). Potato tubers were planted in heated soil, $40 \mathrm{~cm}$ apart, with inter-row spacing of $67.5 \mathrm{~cm}$, on 30 April 2013, 28 April 2014 and 23 April 2015.

A biostimulator and growth regulators were applied in doses recommended by the manufacturers at 10-14 day intervals during the growing season (beginning in stage BBCH 39-crop cover complete). The experiment involved the following treatments:

- $0.1 \%$ solution of the Asahi SL biostimulator (contains natural nitropherols found in plants: ortho-nitropherol, sodium para-nitropherol, sodium 5-nitroguaiacol)—four foliar applications

- $1.0 \%$ solution of Bio-Algeen S-90 (extract from Ascophyllum nodosum brown seaweed, contains amino acids, vitamins, alginic acid and macronutrients: $\mathrm{N}-0.2$, $\mathrm{P}_{2} \mathrm{O} 5-0.06, \mathrm{~K}_{2} \mathrm{O}-0.96, \mathrm{CaO}-3.1, \mathrm{MgO}-2.1 \mathrm{~g} \mathrm{~kg}^{-1}$, and micronutrients: $\mathrm{B}-16.0, \mathrm{Fe}-6.3, \mathrm{Cu}-0.2, \mathrm{Mn}-0.6$, $\mathrm{Zn}-1.0 \mathrm{mg} \mathrm{kg}^{-1}$, and Mo, Se, Co)—four foliar applications,

- $0.2 \%$ solution of Kelpak SL (extract from Ecklonia maxima brown algae, contains $11 \mathrm{mg} \mathrm{dm}^{-3}$ auxins and $0.031 \mathrm{mg} \mathrm{dm}^{-3}$ cytokines)—coating seed potatoes and twice foliar applications,

- Trifender WP (contains Trichoderma asperellum fungal spores at a concentration of $5 \times 10^{8} / \mathrm{g}$ of the product, T1 isolate, NCAIM 68/2006) - applied to soil and four foliar applications.

Plots where growth regulators were not applied were the control.

All plots were subjected to identical cultivation treatments (according to the recommendations of the Institute of Soil Science and Plant Cultivation in Puławy), and weeds were controlled mechanically. Pests were controlled (ac- 
Fig. 1 Symptoms of disease caused by Phytophthora infestans on potato plant depending on cultivar (Ii \%)

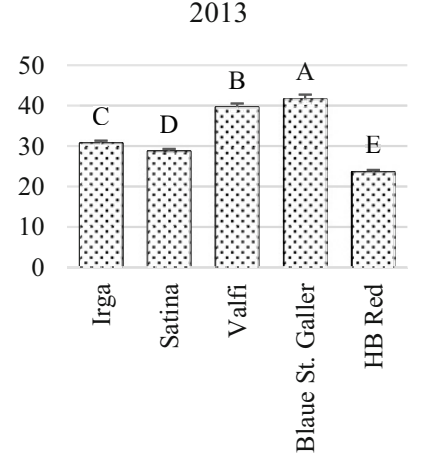

cording to the recommendations of the Institute of Plant Protection in Poznań) with thiacloprid at $0.1 \mathrm{dm}^{3} \mathrm{ha}^{-1}$, acetamipirid at $0.08 \mathrm{~kg} \mathrm{ha}^{-1}$, lambda-cyhalothrin at $0.16 \mathrm{dm}^{3}$ $\mathrm{ha}^{-1}$; and pathogens were controlled in stage BBCH 20-89 with propamocarb hydrochloride and fluopicolide at $1.4 \mathrm{dm}^{3}$ ha $^{-1}$, propamocarb hydrochloride and fenamidone at $2 \mathrm{dm}^{3}$ $\mathrm{ha}^{-1}$, dimethomorph and mancozeb at $2 \mathrm{~kg} \mathrm{ha}^{-1}$, and mancozeb and cymoxanil at $2 \mathrm{~kg} \mathrm{ha}^{-1}$. Potato plants were naturally infected by pathogens. Tubers were harvested on 26 August 2013 and 2014, 28 August 2015.

The severity of late blight (Phytophthora infestans) and early blight (Alternaria solani, A. alternata) was evaluated three times during the experiment on a 9-point scale (Pietkiewicz 1985; 1-no symptoms, 9-all leaves damaged, shoots partially or completely dry). The results were expressed as a percentage by calculating the infection index Ii according to the formula proposed by McKinney (Lacicowa 1970):

infection index $I i=\frac{\sum(\mathrm{a} \cdot \mathrm{b}) \cdot 100 \%}{N \cdot I}$

where

$(a \cdot b)$ sum of the products of the number of analyzed plants (a) and their severity scores (b)

$N \quad$ total number of analyzed plants

I highest severity score.

Potato tuber yield was calculated in three size fractions: horizontal tuber diameter $<35 \mathrm{~mm}, 35-50 \mathrm{~mm}$ and $>50 \mathrm{~mm}$.

The results were processed statistically by ANOVA, and all calculations were performed in the Statistica ${ }^{\circledR} 10.0$ program (StatSoft, USA). Mean values were compared by Duncan's test at a significance level of 0.05 . The relationships between tuber yield and the severity of infections caused by the analyzed pathogens (infection index, \%) during the growing season were determined by linear regression analysis. Coefficients of linear correlation (Pearson's $r$ ) were calculated.

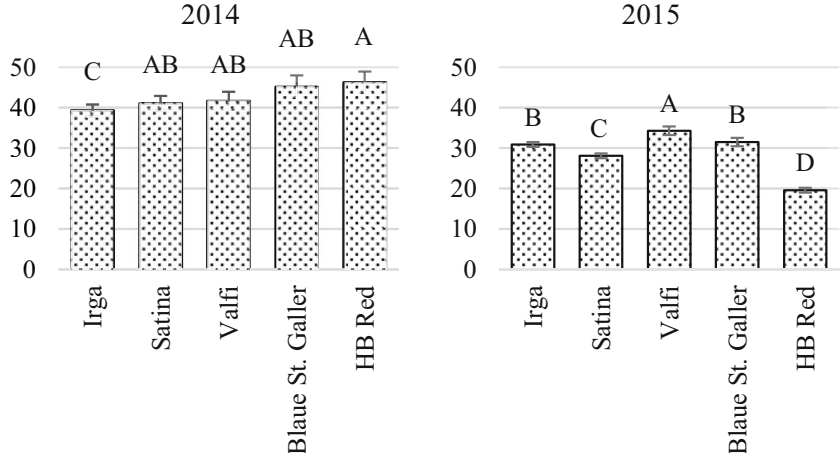

\section{Results and Discussion}

\section{Severity of Late Blight and Early Blight}

The average monthly temperatures between May and $\mathrm{Au}-$ gust in 2013-2015 were similar to the long-term average. In the analyzed months, total precipitation was consistent with the long-term average in the first year of the experiment and was $24 \%$ below the long-term average in the second year. Weather conditions in the first two growing seasons were conducive to the spread of Phytophthora infestans infections. The second year of the study was characterized by low temperatures and low precipitation levels in May and more equally distributed precipitation in the summer months, and it was less favorable for potato cultivation than the first year. Weather conditions in 2014 were also more conducive to the spread of late blight. In the growing season of 2015, precipitation reached $155.4 \mathrm{~mm} \mathrm{(43 \%}$ lower than the long-term average), which contributed to the spread of early blight (Table 1).

Late blight was most prevalent ( $\geq 50 \%)$ in 2014 in cv. Valfi and Blaue St. Galler treated with Bio-Algeen S-90 and Kelpak SL growth regulators, and in cv. HB Red treated with Trifender WP (Table 2). The disease was less prevalent in the remaining years of the experiment, and the highest values of the infection index were noted in untreated potatoes of cv. Valfi (44.1\% in 2013 and $36.0 \%$ in 2015). An analysis of average values of the infection index revealed significant differences in the prevalence of late blight between cultivars and years (Fig. 1). HB Red was the least infected cultivar in the first and last year of the study, and its infection index values differed significantly in comparison with the remaining cultivars. Potato cvs. Irga and Satina (with cream- and yellow-colored flesh) were healthier than Valfi and Blaue St. Galler (with purple-colored flesh), in the analyzed period. Tierno and Ruiz de Galarreta (2016) reported that HB Red with red-colored flesh is susceptible to infections caused by Phytophthora infestans, whereas Valfi with purple-colored flesh is moderately sensitive to this pathogen. Hamouz et al. (2010) demonstrated that the 
Table 3 Infection of potato plants by Alternaria alternata i A. solani (Ii \%)

\begin{tabular}{|c|c|c|c|c|c|c|c|c|c|c|c|c|c|c|c|}
\hline \multirow[t]{2}{*}{ Treatment } & \multicolumn{5}{|l|}{2013} & \multicolumn{5}{|l|}{2014} & \multicolumn{5}{|l|}{2015} \\
\hline & Irga & Satina & Valfi & Blaue & $\begin{array}{l}\text { HB } \\
\text { Red }\end{array}$ & Irga & Satina & Valfi & Blaue & $\begin{array}{l}\text { HB } \\
\text { Red }\end{array}$ & Irga & Satina & Valfi & Blaue & $\begin{array}{l}\text { HB } \\
\text { Red }\end{array}$ \\
\hline Control & $19.5^{\mathrm{ab}}$ & $13.8^{\mathrm{cd}}$ & $19.4^{\mathrm{ab}}$ & $17.6^{\mathrm{abc}}$ & $6.2^{\mathrm{e}}$ & $12.6^{\mathrm{abc}}$ & $12.1^{\mathrm{a}-\mathrm{d}}$ & $9.8^{\mathrm{b}-\mathrm{f}}$ & $9.2^{\mathrm{def}}$ & $8.2^{\mathrm{ef}}$ & $29.9^{\mathrm{a}}$ & $21.0^{\mathrm{b}}$ & $18.7^{\mathrm{bc}}$ & $17.6^{\mathrm{b}-\mathrm{e}}$ & $12.8^{\mathrm{e}}$ \\
\hline Asahi & $20.1^{\mathrm{ab}}$ & $18.2^{\mathrm{abc}}$ & $19.2^{\mathrm{a}}$ & $17.3^{\mathrm{abc}}$ & $9.3^{\mathrm{e}}$ & $12.9^{\mathrm{ab}}$ & $13.0^{\mathrm{ab}}$ & $9.6^{\mathrm{c}-\mathrm{f}}$ & $9.5^{\mathrm{c}-\mathrm{f}}$ & $9.1^{\mathrm{def}}$ & $22.7^{\mathrm{b}}$ & $20.2^{\mathrm{b}}$ & $17.3^{\mathrm{b}-\mathrm{e}}$ & $17.5^{\mathrm{b}-\mathrm{e}}$ & $13.1^{\mathrm{de}}$ \\
\hline Bio-Al. & $31.7^{\mathrm{a}}$ & $17.3^{\mathrm{abc}}$ & $18.3^{\mathrm{abc}}$ & $17.1^{\mathrm{abc}}$ & $9.3^{\mathrm{e}}$ & $11.8^{\mathrm{a}-\mathrm{d}}$ & $14.0^{\mathrm{a}}$ & $10.1^{\mathrm{b}-\mathrm{f}}$ & $10.2^{\mathrm{b}-\mathrm{e}}$ & $9.3^{\mathrm{c}-\mathrm{f}}$ & $19.1^{\mathrm{bc}}$ & $19.6^{\mathrm{b}}$ & $18.4^{\mathrm{bcd}}$ & $19.1^{\mathrm{bc}}$ & $13.5^{\mathrm{de}}$ \\
\hline Kelp. & $19.8^{\mathrm{ab}}$ & $16.9^{\mathrm{abc}}$ & $15.3^{\mathrm{bc}}$ & $18.1^{\mathrm{abc}}$ & $8.8^{\mathrm{e}}$ & $9.7^{\mathrm{b}-\mathrm{f}}$ & $12.1^{\mathrm{a}-\mathrm{d}}$ & $10.1^{\mathrm{b}-\mathrm{f}}$ & $11.7^{\mathrm{a}-\mathrm{d}}$ & $9.5^{\mathrm{c}-\mathrm{f}}$ & $22.2^{\mathrm{b}}$ & $19.1^{\mathrm{bc}}$ & $18.2^{\mathrm{bcd}}$ & $17.6^{\mathrm{b}-\mathrm{e}}$ & $13.4^{\mathrm{de}}$ \\
\hline Trif. & $19.1^{\mathrm{ab}}$ & $17.6^{\mathrm{abc}}$ & $19.0^{\mathrm{ab}}$ & $17.1^{\mathrm{abc}}$ & $9.3^{\mathrm{e}}$ & $12.9^{\mathrm{ab}}$ & $14.4^{\mathrm{a}}$ & $9.0^{\mathrm{def}}$ & $10.0^{\mathrm{b}-\mathrm{f}}$ & $6.8^{\mathrm{f}}$ & $20.9^{\mathrm{b}}$ & $19.6^{\mathrm{b}}$ & $17.7^{\mathrm{b}-\mathrm{e}}$ & $17.3^{\mathrm{b}-\mathrm{e}}$ & $14.1^{\text {cde }}$ \\
\hline
\end{tabular}

Explanations as in Table 2

content of phenolic compounds in potato tubers of cv. Valfi was 2.46 to 3.18 -fold higher than in cultivars with yellowcolored flesh. Kröner et al. (2012) and Brazinskiene et al. (2014) did notobserve significant correlations between the phenolic acid content of potato tubers and the spread of P. infestans. According to the cited authors, the incidence of disease is more likely to be influenced by the production system than the phenolic acid content of tubers.

In all experimental years, the applied growth regulators and biostimulator reduced the severity of late blight in traditional cultivars Irga and Satina, but the observed differences were not significant relative to the control treatment (excluding Irga treated with Kelpak in 2013). In 2013, infection severity was significantly reduced in cv. Valfi treated with Bio-Algeen S-90, Kelpak SL and Trifender WP, and in cv. Blaue St. Galler treated with Trifender WP. In an in vitro study by Stephan et al. (2005), ELOT-Vis (growth regulator containing plant extracts, available on the German market) effectively inhibited the growth of Phytophthora infestans. ELOT-Vis combined with a 5\% aqueous extract of Rheum rhabarbarum completely inhibited mycelial growth, which was stimulated by the addition of an aqueous extract of $\mathrm{Sol}$ idago canadensis. In a study exploring alternative solutions to copper-based compounds, products containing Bacillus subtilis and Trichoderma spp. influenced the severity of leaf infections with Phytophthora infestans, subject to the date of application (Stephan et al. 2005). Kowalska and Remlein-Starosta (2012) demonstrated that one soil treatment and four foliar treatments with the Trichoderma asperellum fungus were as effective in reducing the severity of late blight in potatoes of cv. Impala as two applications of the copper-based fungicide Miedzian 50 WP. In the potato cv. Tajfun subjected to ten foliar applications of T. asperellum, the severity of the disease was reduced by around $30 \%$ relative to unprotected plants. Sawicka (2003) demonstrated that the combined application of the Asahi SL biostimulator and foliar fertilizers delayed $P$. infestans infections in a potato farm and prolonged plant growth by 2 to 14 days, subject to cultivar. In a study by Sawicka and Skiba (2009), the Asahi SL delayed the first symptoms of $P$. infestans infection by 3 to 7 days. Cwalina-Ambroziak et al. (2015) reported a decrease in the severity of late blight in potatoes of cv. Irga and Satina treated with Bio-Algeen S-90 and Kelpak SL growth regulators. In a study by Uromova et al. (2016), greenhouse-grown potatoes of cv. Udacha were characterized by higher resistance to late blight after the application of the Agat-25K growth regulator.

In the present experiment, the prevalence of Alternaria spp. was lowest in 2014 when weather conditions were more conducive to the spread of late blight. The lowest value of the infection index (6.8\%) was noted in HB Red plants treated with Trifender WP, and it differed significantly from the values noted in cv. Irga (excluding the Kelpak SL treatment) and cv. Satina (Table 3). The highest value of the infection index $(29.9 \%)$ was observed in untreated potatoes of $\mathrm{cv}$. Irga in the last year of the study (2015). HB Red was also least susceptible to early blight in the remaining years of the experiment, and its index values differed significantly relative to the remaining cultivars in 2013, and relative to Irga and Satina in 2015. In plots were growth regulators and the biostimulator were applied, the severity of disease was significantly reduced in cv. Irga in 2015. An analysis of average values for the entire experiment revealed that HB Red was significantly less infected by Alternaria spp. (Fig. 2). Infections caused by $A$. alternata have been shown to increase the content of phenolic acids in tomatoes (López-Gresa et al. 2011; Wojciechowska et al. 2014). Plants rapidly accumulate phenolic compounds in response to a pathogenic infection (Gogoi et al. 2001). According to Sawicka and Krochmal-Marczak (2008), Asahi SL is highly effective in reducing the spread of early blight in potatoes. This biostimulator is particularly useful under adverse weather conditions. Sawicka and Skiba (2009) demonstrated that in plants treated with Asahi SL, the infection of $50 \%$ of the leaf area by $P$. infestans was delayed by 22 days. Cwalina-Ambroziak et al. (2015) informed a decrease the severity of early blight in potatoes of cv. Irga and Satina in the treatments where Asahi SL, Bio-Algeen S-90 and Kelpak SL growth regulators were applied. In a study by Chowdappa et al. (2013), isolates of Trichoderma harzianum OTPB3 inhibited mycelial growth of $A$. solani and P. infestans in vitro. 
Fig. 2 Symptoms of disease caused by Alternaria alternata, A. solani on potato plant depending on cultivar (Ii \%)
Fig. 3 Potato yield depending on factors of experience ( $\mathrm{dt}$ $\left.\mathrm{ha}^{-1}\right)$. a cultivar, $\mathbf{b}$ treatment

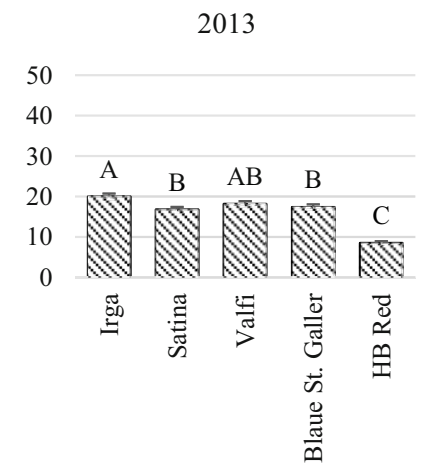

a

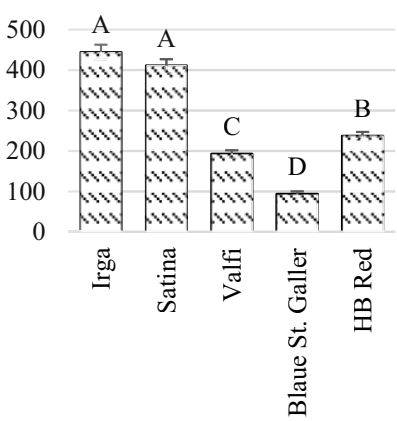

b

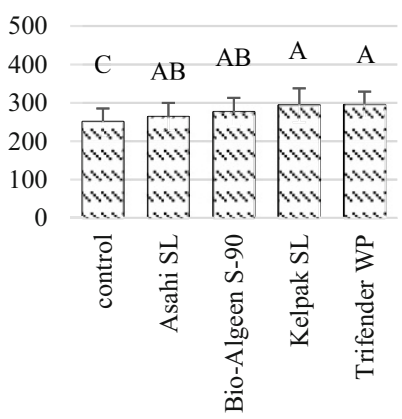

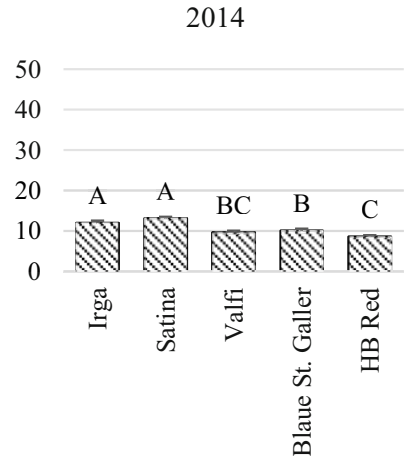

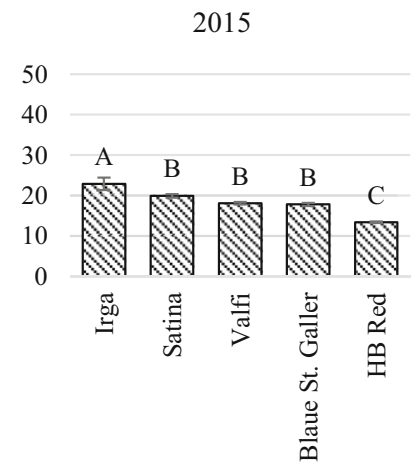

2014

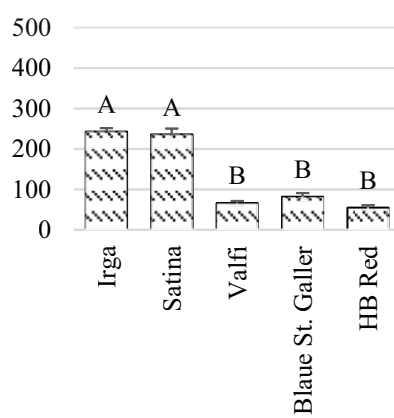

2015

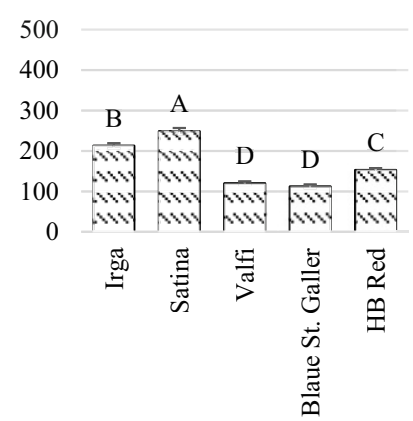

2014

2015

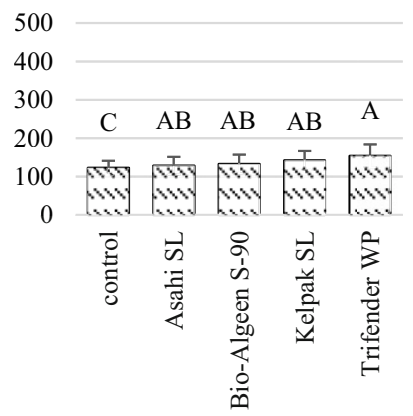

In tomato seedlings, the fungal spore suspension enhanced systemic resistance through induction of growth hormones (indole-3-acetic acid, IAA and gibberellic acid, GA3) and defense-related enzymes (peroxidase, polyphenol oxidase and superoxide dismutase). Hernández-Herrera et al. (2014) demonstrated that application of extracts from green (Ulva lactuca, Caulerpa sertularioides) and brown alga (P. gymnospora, Sargassum liebmannii) have suppressive effects on Alternaria solani infecting tomato.

\section{Yield and Size of Potato Tubers}

An analysis of average values revealed that the yield of Irga and Satina tubers in all treatments significantly exceeded the yield of remaining potato cultivars in all experimental years (Table 4, Fig 3a). The above cultivars produced the highest yields in the first year of the study, and Irga potatoes treated with Klepak SL was characterized by the heaviest tubers $\left(524.67 \mathrm{dt} \mathrm{ha}^{-1}\right)$. In the remaining two years, traditional cultivars were characterized by similar yields, and the highest yields were noted in 2014 in cv. Satina treated with Trifender WP (around $290 \mathrm{dt} \mathrm{ha}^{-1}$ ). The yield of potato tubers treated with growth regulators increased in Irga and Satina cultivars in the first two years of the study, in cv. HB Red in the first year of the study. The tested growth regulators Kelpak SL and Bio-Algeen S-90 induced a significant increase in the tuber yield of cvs. Irga and HB Red, respectively, in the first year of the experiment, and Trifender WP increased the tuber yield of cv. Satina in the second year. In general, the growth regulators and biostim- 


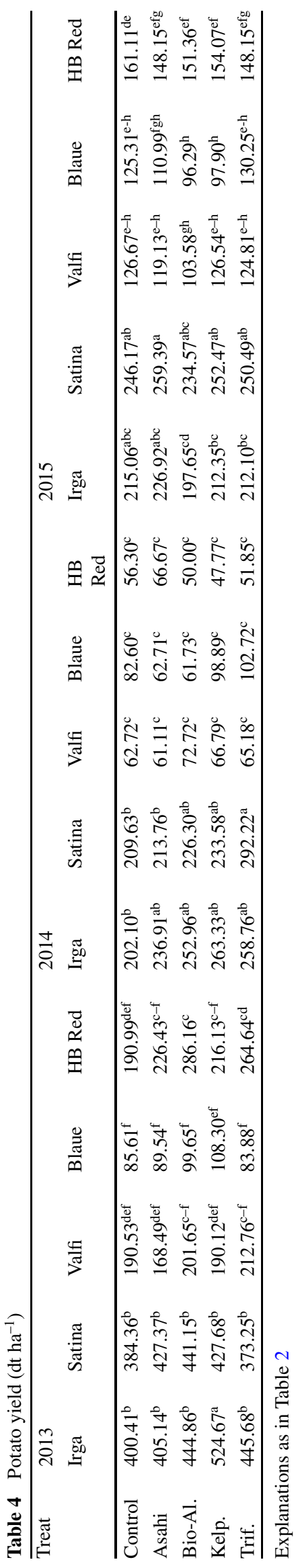

ulator increased potato yields in 2013 and 2014 (Fig. 3b). Czeczko and Mikos-Bielak (2004) demonstrated that the yield of potato tubers increased by around $14 \%$ already after one foliar application of Asahi SL. In a study by Kowalska and Remlein-Starosta (2012), the yield of potato tubers treated with Trifender WP was nearly two-fold higher than the yield of untreated plants. According to Wierzbowska et al. (2015), Bio-Algeen S-90 and Kelpak SL growth regulators increased the tuber yield of Irga by $8.9 \%$ and $15.6 \%$, respectively, and the tuber yield of Satina by $14.7 \%$ and $18.3 \%$, respectively. The cited authors also reported an increase in the nitrate $(\mathrm{V})$ content of tubers harvested from potato plants treated with Kelpak SL. Haider et al. (2012) evaluated an organic biostimulator containing algae extracts which was applied to the leaves of potato plants of cv. Sante. The evaluated product increased plant growth parameters, including plant height, number of stems, tuber yield and tuber quality (higher content of dry matter, protein, N, P and K). In a study by Uromova et al. (2016), the HB-101 growth regulator increased the tuber yield of Udacha potatoes grown in a greenhouse.

In the first two years of the study, large and mediumsized tubers accounted for approximately $84 \%$ and $77 \%$ in cv. Irga and Satina, respectively (with a $50 \%$ share of medium-sized tubers), which was reflected in tuber yield (Table 5). In the first year of the study, the applied growth regulators and biostimulator significantly increased the percentage of medium-sized tubers of cv. Blaue St. Galler, and Bio-Algeen S-90 increased the percentage of mediumsized tubers of cv. HB Red. In potato cvs. Valfi, Blaue St. Galler and HB Red (with colored flesh), large tubers were noted sporadically in all years of the experiment. The highest percentage of medium-sized tubers in the total yield was observed in cv. Valfi (58\%) in the first year of the study, and in cv. Valfi and Blaue St. Galler $(50 \%)$ in the second year of the experiment. In the last year of the study, potato cultivars Valfi, Blaue St. Galler and HB Red (with purpleand red-colored flesh) were characterized by predominance (76-92\%) of small tubers. According to Bohl et al. (2011), growth regulators decrease the percentage of medium-sized potato tubers. Blauer et al. (2013) demonstrated that the application of gibberellic acid (GA) decreased the percentage of tubers weighing $198 \mathrm{~g}$ and more and increased the share of smaller tubers in red-skinned potatoes of cv. Chieftain. The tuber yield of cv. Chieftain and Satina differed subject to GA concentration. Thornton et al. (2014) observed that ethephon (2-chloroethylphosphonic acid) can decrease the average size of potato tubers. Foliar application of ethephon to red-skinned potatoes of cv. LaSoda increased the percentage of small tubers, but did not decrease marketable yield (Buhrig et al. 2015). 


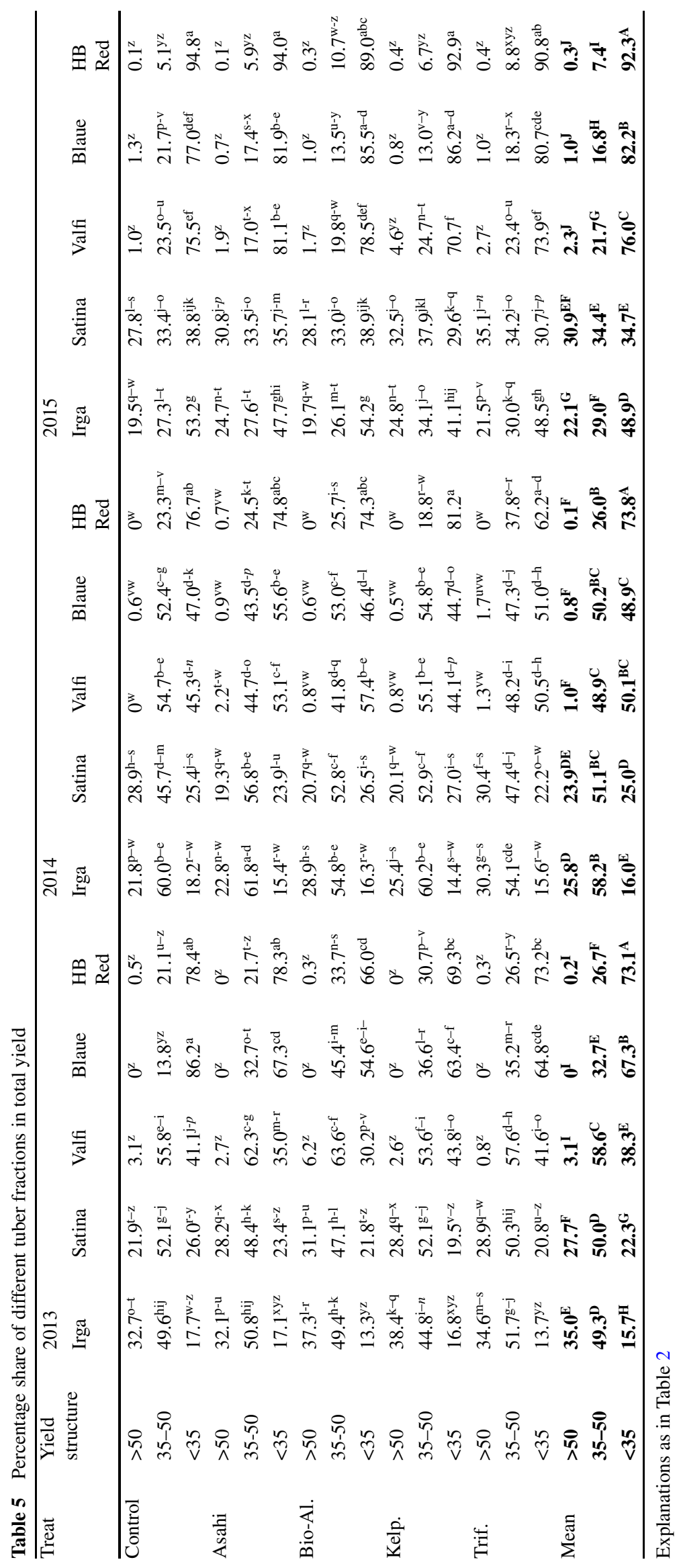


Fig. 4 Relationships between tuber yield and percentage of infected plants by P. infestans
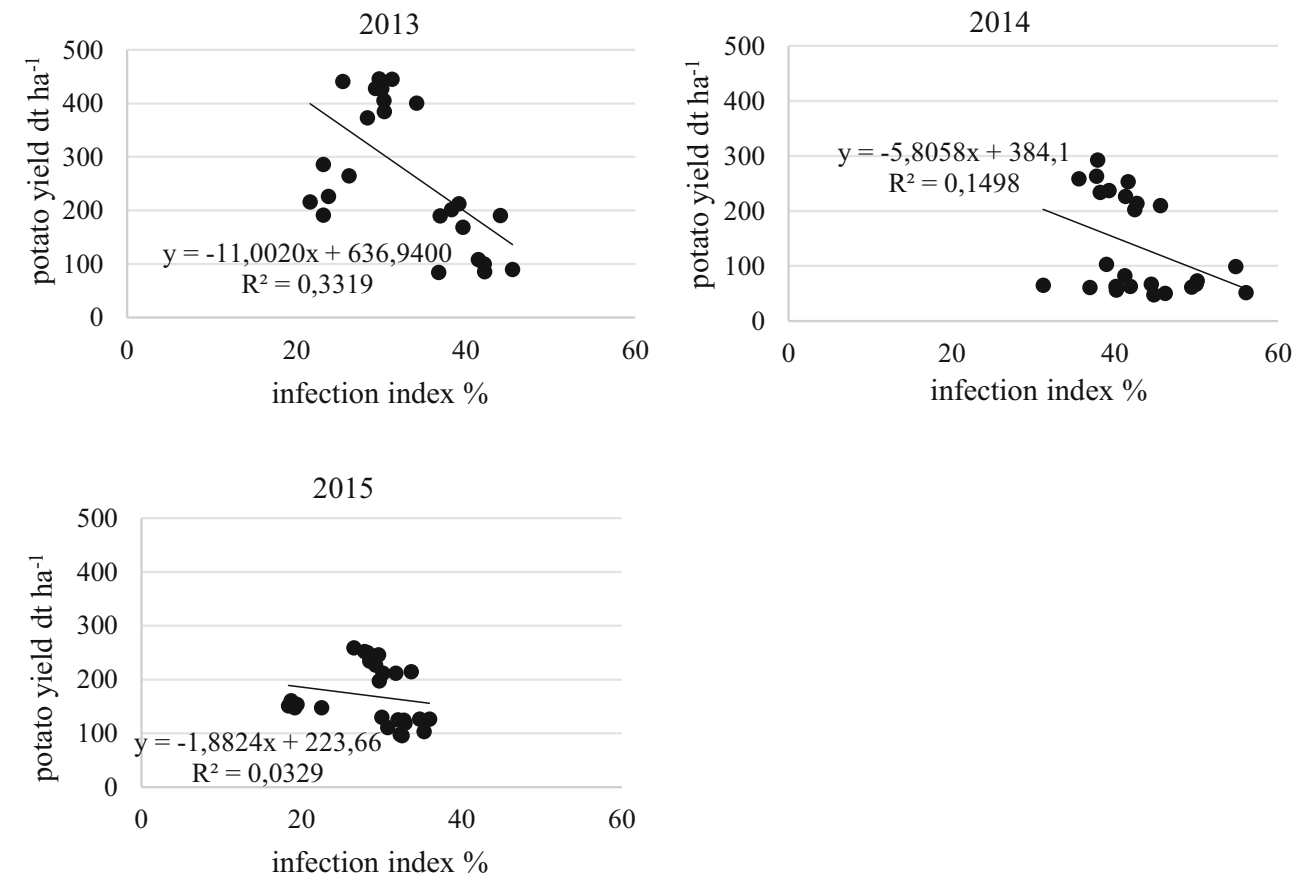

\section{Assessment of Potato Tuber Yield by Linear Regression Analysis}

In this experiment, potato tuber yield was influenced by the severity of $P$. infestans infections during the growing season. Tuber yield decreased with a rise in the prevalence of late blight in the analyzed period of 2013-2015, as revealed by the calculated coefficients of correlation (Pearson's $r$ ): $r=-0.576, r=-0.387, \mathrm{r}=-0.182$, respectively (Fig. 4). In contrast, tuber yield was not correlated with the prevalence of Alternaria spp. infections during the study. Kowalska (2016) demonstrated that yield is not directly correlated with the severity of disease, and a real drop in yield is noted only when more than $60 \%$ of plants are infected with P. infestans and Alternaria spp. The products tested in the cited study (Bioilsa Fertil NC, EM Farma Plus, UGmax) delayed the onset of disease, prolonged the growing season (in particular when disease severity was low) and protected crops. Runno-Paurson et al. (2014) reported higher tuber yields in treatments where intercropping and manure fertilizers were used. Potato leaves were more severely infected with Alternaria spp. in the above treatments than in intercropped treatments where manure fertilizers were not applied. According to the above authors, potato tuber yield is less influenced by early blight than by manure application.

\section{Conclusions}

The analyzed growth regulators significantly reduced the symptoms of Phytophthora infestans infection in one year
(2013) out of the three experimental years. The tested growth stimulators, Kelpak SL in cv. Irga (cream-colored flesh), Bio-Algeen S-90, Kelpak SL and Trifender WP in cv. Valfi and Trifender WP in cv. Blaue St. Galler (purplecolored flesh), reduced the severity of late blight in the first year of the study. The severity of early blight was decreased in cv. Irga treated with all growth stimulators and the biostimulator in the last year of the study (2015). Highland Burgundy Red (red-colored flesh) was characterized by the best health status (except in 2014 when it was infected by $P$. infestans). A significant increase in tuber yield was noted in cv. Irga treated with Kelpak SL and in cv. HB Red treated with Bio-Algeen S-90 in 2013, and in cv. Satina treated with Trifender WP in 2014. In the first year of the study, the applied growth regulators and biostimulator significantly increased the percentage of mediumsized tubers of cv. Blaue St. Galler, and Bio-Algeen S-90 increased the percentage of medium-sized tubers of $\mathrm{cv}$. HB Red. Potato tuber yield decreased with a rise in the severity of late blight.

Conflict of interest M. Głosek-Sobieraj, B. Cwalina-Ambroziak and $\mathrm{K}$. Hamouz declare that they have no competing interests.

Open Access This article is distributed under the terms of the Creative Commons Attribution 4.0 International License (http:// creativecommons.org/licenses/by/4.0/), which permits unrestricted use, distribution, and reproduction in any medium, provided you give appropriate credit to the original author(s) and the source, provide a link to the Creative Commons license, and indicate if changes were made. 


\section{References}

Bellumori M, Innocenti M, Michelozzi M, Cerretani L, Mulinacci N (2017) Coloured-fleshed potatoes after boiling: promising sources of known antioxidant compounds. J Food Compost Anal 59:1-7. https://doi.org/10.1016/j.jfca.2017.02.004

Blauer J, Knowles LO, Knowles NR (2013) Manipulating stem number, tuber set and size distribution of specialty potato cultivars. Am J Potato Res 90:470-496. https://doi.org/10.1007/s12230013-9317-0

Bohl WH, Stark JC, McIntosh CS (2011) Potato seed piece size, spacing, and seeding rate effects on yield, quality and economic return. Am J Potato Res 88:470-478. https://doi.org/10.1007/ s12230-011-9213-4

Bradeen JM, Lorizzo M, Mollov DS, Raasch J, Kramer LC, Millet PB, Austin-Phillips S, Jiang J, Carputo D (2009) Higher copy numbers of the potato RB transgene correspond to enhanced transcript and late blight resistance levels. Mol Plant-microbe Interact 22:437-446. https://doi.org/10.1094/MPMI-22-4-0437

Brazinskiene V, Asakaviciute R, Miezeliene A, Alencikiene G, Ivanauskas L, Jakstas V, Viskelis P, Razukas A (2014) Effect of farming systems on the yield, quality parameters and sensory properties of conventionally and organically grown potato (Solanum tuberosum L.) tubers. Food Chem 145:903-909. https:// doi.org/10.1016/j.foodchem.2013.09.011

Brown CR (2005) Antioxidants in potato. Am J Potato Res 82:163-175. https://doi.org/10.1007/BF02853654

Buhrig W, Thornton MK, McIntosh C, Olsen N, Morishita D (2015) The influence of foliar ethephon application on economic returns of Red LaSoda potatoes. Am J Potato Res 92:697-703. https:// doi.org/10.1007/s12230-015-9479-z

Bulgari R, Cocetta G, Trivellini A, Vernieri P, Ferrante A (2015) Biostimulants and crop responses: a review. Biol Agric Hortic 31(1):1-17. https://doi.org/10.1080/01448765.2014.964649

Chmielarz M, Sobkowiak S, Dębski K, Cooke DEL, Brurberg MB, Śliwka J (2014) Diversity of Phytophthora infestans from Poland. Plant Pathol 63:203-211. https://doi.org/10.1111/ppa.12076

Chowdappa P, Mohan Kumar SP, Jyothi Lakshmi M, Upreti KK (2013) Growth stimulation and induction of systemic resistance in tomato against early and late blight by Bacillus subtilis OTPB1 or Trichoderma harzianum OTPB3. Biol Control 65(1):109-117. https:// doi.org/10.1016/j.biocontrol.2012.11.009

Cooke LR, Schepers HTAM, Hermansen A, Bain RA, Bradshaw NJ, Ritchie F, Shaw DS, Evenhius A, Kessel GJT, Wander JGN, Andersson B, Hansen JG, Hannukkala A, Naerstad R, Nielsen BJ (2011) Epidemiology and integrated control of potato late blight in Europe. Potato Res 54:183-222. https://doi.org/10.1007/ s11540-011-9187-0

Cwalina-Ambroziak B, Głosek-Sobieraj M, Kowalska E (2015) The effect of plant growth regulators on the incidence and severity of potato diseases. Pol J Nat Sci 30(1):5-20

Czeczko R, Mikos-Bielak M (2004) Effects of Asahi bio-stimulator application in the cultivation of different vegetable species. Ann Univ Mariae Curie Sklodowska, Sec E 59(3):1073-1079 (in Polish)

Dixon RA (2001) Natural products and plant disease resistance. Nature 411:843-847. https://doi.org/10.1038/35081178

Ezekiel R, Singh N, Sharma S, Kaur A (2013) Beneficial phytochemicals in potato-a review. Food Res Int 50:487-496. https://doi. org/10.1016/j.foodres.2011.04.025

Fry W (2008) Phytophthora infestans: the plant (and R gene) destroyer. Mol Plant Pathol 9:385-402. https://doi.org/10.1111/j. 1364-3703.2007.00465.x

Gogoi R, Singh DV, Srivastava KD (2001) Phenols as a biochemical basis of resistance in wheat against karnal bunt. Plant Pathol 50:470-476. https://doi.org/10.1046/j.1365-3059.2001.00583.x
Gudmestad NC, Pasche JS (2007) Role of fenamidone in the management of potato early blight—Alternaria solani. In: H.T.A.M. Schepers (ed) Special Report no. 12, pp 175-182 (Appl. Plant Res., Wageningen UR, PPO 370, 368 pp.)

Haider MW, Ayyub CM, Pervez MA, Asad HU, Manan A, Raza SA, Ashraf I (2012) Impact of foliar application of seaweed extract on growth, yield and quality of potato (Solanum tuberosum L.). Plant Soil Environ 31:157-162

Hamouz K, Lachman J, Hejtmánková K, Pazderů K, Čížek M, Dvořák $P$ (2010) Effect of natural and growing conditions on the contentof phenolics in potatoes with different flesh colour. Plant Soil Environ 56:368-374

Hausladen H, Leiminger J (2007) Potato early blight in Germany (Alternaria solani, Alternaria alternata). In: H.T.A.M. Schepers (ed) Special Report no. 12, pp 189-194 (Appl. Plant Res., Wageningen UR, PPO 370, 368 pp)

Hernández-Herrera RM, Virgen-Calleros G, Ruiz-López M, ZañudoHernández J, Délano-Frier JP, Sánchez-Hernández C (2014) Extracts from green and brown seaweeds protect tomato (Solanum lycopersicum) against the necrotrophic fungus Alternaria solani. J Appl Phycol 26:1607-1614

Kapsa J (2005) Harnessing the natural defense mechanisms of potato varieties in the prevention of late blight. Ziemn Pol 4:20-22 (in Polish)

Kapsa J (2007) Application of the Burkard spore trap to determine a composition of the genus Alternaria in potato crops. Biul Inst Hodowli Aklim Roslin 244:223-229 (in Polish)

Kapsa J, Hansen JG (2004) Establishment of a monitoring network for potato late blight (Phytophthora infestans) in Poland. Plant Breed Seed Sci 50:63-70

Kowalska J (2016) Effect of fertilization and microbiological bio-stimulators on healthiness and yield of organic potato. Prog Plant Prot 56(2):230-235 (in Polish)

Kowalska J, Remlein-Starosta D (2012) Influence of frequency and way of application of bio-preparate (Trichoderma asperellum) on limitation of potato late blight and yield of organic potato. Prog Plant Prot 52(2):347-350 (in Polish)

Kröner A, Marnet N, Andrivon D, Val F (2012) Nicotiflorin, rutin and chlorogenic acid: phenylpropanoids involved differently in quantitative resistance of potato tubers to biotrophic and necrotrophic pathogens. Plant Physiol Biochem 57:23-31. https://doi.org/10. 1016/j.plaphy.2012.05.006

Łacicowa B (1970) Investigations on Helminthosporium sorokinianum $(=$ H. sativum $)$ strains and on the resistance of spring barley varieties to this pathogenic factor. Acta Mycol 6(2):184-248 (in Polish)

Latijnhouwers M, Ligterink W, Vleeshouwers VG, VanWest P, Govers F (2004) A G $\alpha$ subunit controls zoospore mobility and virulence in the potato late blight pathogen Phytophthora infestans. Mol Microbiol 51:925-936

López-Gresa MP, Torres C, Campos L, Lisón P, Rodrigo I, Bellés JM, Conejero V (2011) Identification of defence metabolites in tomato plants infected by the bacterial pathogen Pseudomonas syringae. Environ Exp Bot 74:216-228. https://doi.org/10.1016/j. envexpbot.2011.06.003

Mandal SM, Chakraborty D, Dey S (2010) Phenolic acids act as signaling molecules in plant-microbe symbioses. Plant Signal Behav $5: 359-368$

Mosquera T, Alvarez MF, Jiménez-Gómez JM, Shehabu Muktar M, João Paulo M, Steinemann S, Li J, Draffehn A, Hofmann A, Lübeck J, Strahwald J, Tacke E, Hofferbert HR, Walkemeier B, Gebhardt C (2016) Targeted and untargeted approaches unravel novel candidate genes and diagnostic SNPs for quantitative resistance of the potato (Solanum tuberosum L.) to Phytophthora infestans causing the late blight disease. PLoS ONE 11(6):1-36. https://doi.org/10.1371/journal.pone.0156254 
Pietkiewicz JB (1985) A method for evaluating the severity of late blight (Phytophthora infestans) symptoms on the aerial parts of potato plants. Biul Inst Ziemn 32:51-62 (in Polish)

Runno-Paurson E, Hansen M, Tein B, Loit K, Jõgi K, Luik A, Metspalu L, Eremeev V, Williams IH, Mänd M (2014) Cultivation technology influences the occurrence of potato early blight (Alternaria solani) in an organic farming system. Zemdirb Agric 101(2):199-204. https://doi.org/10.13080/z-a.2014.101.026

Sawicka B (2003) The effect of combined application the agrochemicals on speed of spread of Phytophthora infestans in potato plant. Acta Agrophys 85:157-168 (in Polish)

Sawicka B, Krochmal-Marczak B (2008) The effects of combined application of foliar fertilizers and bioregulators of growth in the cultivation of new varieties of potato. Scientific Conference „Foliar fertilization“, Lublin, September 18-19, p. 40

Sawicka B, Skiba D (2009) Influence of foliar nutrition on plant sanitary conditions in vegetation period of potato. Ann Univ Mariae Curie Sklodowska, Sec E 64(2):39-51 (Sec. E; in Polish)

Sharma HS, Fleming C, Selby C, Rao JR, Martin T (2014) Plant biostimulants: a review on the processing of macroalgae and use of extracts for crop management to reduce abiotic and biotic stresses. J Appl Phycol 26:465-490. https://doi.org/10.1007/s10811-0130101-9

Smart CD, Fry WE (2001) Invasions by the late blight pathogen: renewed sex and enhanced fitness. Biol Invasions 3:235-243. https://doi.org/10.1023/A:1015200920772

Soleimani MJ, Kirk W (2012) Enhance resistance to Alternaria alternata causing potato brown leaf spot disease by using some plant defense inducers. J Plant Prot Res 52(1):83-90

Stephan D, Schmitt A, Martins Carvalho S, Seddon B, Koch E (2005) Evaluation of biocontrol preparations and plant extracts for the control of Phytophthora infestans on potato leaves. Eur J Plant Pathol 112:235-246. https://doi.org/10.1007/s10658-005-2083-1

Terry LA, Joyce DC, Adikaram NKB, Kambay PBS (2014) Preformed antifungal compounds in strawberry fruit and flower tissues. Postharvest Biol Technol 31:201-210. https://doi.org/10.1016/. postharvbio.2003.08.003

Thornton MK, John R, Buhrig W (2014) Influence of plant growth regulators and inflorescence removal on plant growth, yield, and skin color of Red Lasoda tubers. Potato Res 57:123-131. https:// doi.org/10.1007/s11540-014-9257-1

Tierno R, Ruiz de Galarreta JI (2016) Breeding for nutritional quality and pest resistance: potential of a set of non-commercial tetraploid potato cultivars with purple and red flesh. Rev Latinoam Papa 20(1):9-17

Uromova IP, Koposova NN, Kozlov AV, Shtyrlin DA, Davydova YY (2016) Growth regulators in the technology of reproduction of improved potatoes. Biosci Biotechnol Res Asia 13(1):561-567. https://doi.org/10.13005/bbra/2074

Wierzbowska J, Cwalina-Ambroziak B, Głosek M, Sienkiewicz S (2015) Effect of biostimulators on yield and selected chemical properties of potato tubers. J Elemntology 20(3):757-768. https:// doi.org/10.5601/jelem.2014.19.4.799

Wojciechowska E, Weinert CH, Egert B, Trierweiler B, SchmidtHeydt M, Horneburg B, Graeff-Hönninger S, Kulling SE, Geisen R (2014) Chlorogenic acid, a metabolite identified by untargeted metabolome analysis in resistant tomatoes, inhibits the colonization by Alternaria alternata by inhibiting alternariol biosynthesis. Eur J Plant Pathol 139:735-747. https://doi.org/10.1007/s10658014-0428-3

Ziosi V, Zandoli R, Di Nardo A (2013) Biological activity of different botanical extracts as evaluated by means of an array of in vitro and in vivo bioassays. Acta Hortic 1009:61-66. https://doi.org/ 10.17660/ActaHortic.2013.1009.5

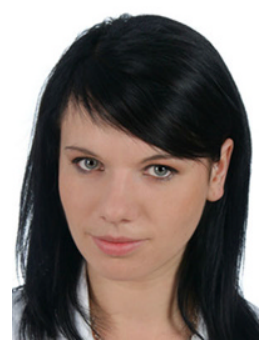

Małgorzata Głosek-Sobieraj was born on 10.07.1987 in Ostrołęka (Poland). She is a PhD student at the Department of Entomology, Phytopathology and Molecular Diagnostics at the University of Warmia and Mazury in Olsztyn (research supervisor is professor Bożena Cwalina-Ambroziak). Her research field is the health status of plants, including the potato; biological control against pathogens; a mechanism of disease resistance in plants. 